\title{
Rapport Dijsselbloem versus de zorgopleidingen
}

De inbreng van Otto Bleker in dit nummer is een artikel over de recente geschiedenis van de modernisering van de medisch specialistische opleidingen. Zijn hartverwarmende kijk op de zorg, zorgers en patiënten stelt de lezer open voor de vanzelfsprekende noodzaak van aanpassing van de specialistenopleidingen. De andere zorgopleidingen vallen grotendeels ook onder zijn argumentatie en ook daar zien we belangrijke aanpassingen in het curriculum.

$\mathrm{Nu}$ in februari 2008 de commissie Dijsselbloem haar kritische rapport over het Nederlandse onderwijsbeleid uitbracht, ${ }^{1}$ is het wel erg aantrekkelijk om de bevindingen van die commissie eens te spiegelen aan het proces van modernisering waarover Otto Bleker rapporteert. Natuurlijk gaat dit rapport over veranderingen in het Nederlandse schoolsysteem en gaat deze vergelijking op enkele fronten mank. Bovendien is op het rapport zelf ook het nodige af te dingen. De ambtelijke taal werkt soms vervreemdend en het rapport vertolkt in zekere mate een tijdgeest en de Nederlandse cultuur. Het verbaast mij niettemin dat er overeenkomsten te vinden zijn, vooral op het terrein van de mij goed bekende modernisering van de medische vervolgopleidingen. In grote lijnen neem ik u mee langs een aantal items die te vinden zijn in de samenvatting op de laatste pagina's van het rapport.

\section{Analyse van problemen schoot te kort} Otto Bleker beschrijft de problematiek van een slechte organisatie waardoor patiënten teveel verschillende artsen zien.
Dit wordt bij onze modernisering geweten aan de gebrekkige organisatievaardigheid van artsen. Misschien zijn effecten van beperkte werktijden, verouderde bestuursvormen als 'de maatschap' en financiering van zorg zonder prikkels op basis van klantperceptie, wel betere aangrijpingspunten om organisatieproblemen op te lossen. Een vaak gestelde vraag is of het wel reëel is om van iedere specialist een schaap met zeven (CanMEDS) poten te maken. Kan een dergelijke exercitie doorschieten? Leidt dat dan niet af van optimale vakbekwaamheid?

\section{Verantwoordelijke bewindslieden vertoonden een tunnelvisie}

Dat durf ik van onze bewindslieden en verantwoordelijke collegae niet te zeggen. Toch staan de vernieuwers en de regelgevers niet erg open voor waarschuwingen en kritiek op een te strak ingezet beleid. Er wordt conform de bevindingen van Dijsselbloem wetgeving ingezet zonder dat deugdelijke pilots en experimenten gedaan zijn.

\section{Politiek draagvlak belangrijker dan draagvlak in het onderwijs}

Als lid van de Begeleidingsgroep Beschrijvingen Opleidingsplannen Vervolgopleidingen (BBOV) herken ik de situatie die beschreven is bij dit item: "Overeenstemming met (red: wetgevers en) het onderwijsveld werd bereikt met de beroepsvertegenwoordigers van belangenorganisaties (red: bijvoorbeeld concilia van wetenschappelijke verenigingen). Zij leken daarmee dichter bij de politiek (red: VWS, 
die flinke druk uitoefent op het CCMS) te staan dan bij hun eigen achterban." We lopen bij evaluatie van de modernisering over enkele jaren het risico dit zelfde probleem voor het voetlicht geworpen te krijgen.

\section{Docenten, ouders en leerlingen onvol- doende gehoord in onderwijspolder}

"De complexiteit van de vernieuwing, de tijdsdruk waaronder dit moest worden ingevoerd en het tekortschieten van faciliteiten, leidden al gauw tot het wegsmelten van draagvlak." Gaan wij dat ook meemaken in ons project van modernisering van de medische vervolgopleidingen?

\section{Veel beleidskeuzen werden bepaald door het financiële kader}

"De bedragen die de overheid voor de onderwijsvernieuwingen beschikbaar stelde, werden bepaald door de beperkte begrotingsruimte en niet door nut en noodzaak, zoals benodigde middelen voor scholing van docenten." Ik heb, in het kader van het 'in VIVO-project' waarbinnen kinderartsen en gynaecologen als pilot volgens de nieuwe visie worden opgeleid, voor VWS eens berekend dat voor een goed begeleide invoering van de modernisering voor de specialistenopleidingen meer dan 50 miljoen Euro nodig is. Dat is er nu niet.

\section{Parallelle ingrijpende veranderingen doorkruisen de vernieuwing}

De invoering van marktwerking bij het opleiden van specialisten lijkt hier zeer toepasselijk. De modernisering van de medische vervolgopleidingen vindt plaats in een tijd van ingrijpende veranderingen van financiering en toewijzing van artsen in opleiding tot specialist (aios). Dat wordt als afleiding ervaren bij het streven naar een grote slag in de kwaliteitsverbetering en vergroot het gevoel van onzekerheid.

\section{Didactische vernieuwingen werden als verplicht ervaren}

Mijn werk bij de BBOV laat dat ook vaak zien. Het is bijvoorbeeld te hopen dat opleidergroepen de verplichte Korte Praktijk Beoordeling (KPB) van kritische beroepssituaties, die licht werpen op het functioneren van de arts in opleiding tot specialist op het terrein van algemene (CanMEDS) competenties en het portfolio, speels zullen weten te gebruiken. De vernieuwing lijkt nu gelijk te staan aan het implementeren van beoordelingsinstrumenten terwijl de ambities en achterliggende gedachtes, als het bewaken van groei, het stimuleren van de eigen verantwoordelijkheid van de aios op basis van een persoonlijk opleidingsplan, op de achtergrond kunnen raken.

\section{Wetenschappelijke onderbouwing van het nieuwe leren ontbreekt grotendeels}

"In dit proces van didactische vernieuwing is een verschuiving zichtbaar van vakinhoud naar algemene vaardigheden als samenwerkend leren .... . De wetenschappelijke onderbouwing van de effectiviteit van sommige 'nieuwe leren'-methoden ontbreekt nog." Ik zou, bijvoorbeeld, zo graag meer lezen over het effect van CanMEDS op een betere patiëntenzorg.

Het rapport geeft adviezen waarvan er enkele voor ons van belang zijn:

- De overheid gaat over 'het wat'; het onderwijs gaat over 'het hoe'. Een definitie van wat de specialist van morgen moet kunnen is zinnig. Een definitie van hoe die dat moet leren is in de ogen van de commissie Dijsselbloem over de grens. Let wel, die grens wordt bij de modernisering ruim gepasseerd.

- Toetsingskader en uitvoeringstoets. Hieronder beschrijft de commissie voorwaarden voor een grote vernieuwing, zoals de 
afweging van beleidsalternatieven, voldoende tijd en financiële middelen voor invoering, en in geval van onvoldoende gevalideerde onderwijsinhoudelijke vernieuwingen deze eerst wetenschappelijk begeleid uitproberen en evalueren. Dat levert het gevoel dat de commissie Dijsselbloem kritisch over ons moderniseringsproces zou oordelen.

- Kritischer omgang scholen met didactische vernieuwingen. Dat klinkt in het kader van de medisch specialistische opleidingen bijna als een oproep tot oproer. Het wetgevende Centraal College Medische Specialismen (CCMS) is niet mals met haar didactische voorschriften en een kritische houding van wetenschappelijke verenigingen wordt meestal niet gehonoreerd, laat staan een dergelijke houding van individuele opleidingsafdelingen. Dit vraagt volgens mij om heroverweging van ingezette strategieën.

\section{Wat kunnen we van bovenstaande ervaringen leren?}

- We moeten ervoor waken ineens en massaal allerlei trendy veranderingen in te voeren. Niet allemaal achter elkaar aanhollen, maar vooral kijken naar waar het eigenlijk om draait: professionals opleiden die kunnen instaan voor goede patiëntenzorg.

- De wetgever moet zeer globale toetsingskaders hanteren voor de vormgeving van de opleiding op de werkvloer.

- Er moet een in VIVO-2-project komen om naast de Nederlandse Verenigingen voor Kindergeneeskunde en voor Obstetrie en Gynaecologie ook de andere verenigingen financieel te ondersteunen bij de uitvoering van hun opleidingsplannen.

- Er moet tijd en geld zijn voor pilots en voor onderbouwing van de diverse instrumenten en methodieken, dus veel aandacht voor 'evidence based education'.

- De wetgever moet rekening houden met een behoorlijke tijdsduur voordat een goed overwogen en volledige implementatie zijn beslag heeft gekregen.

\section{Wat hebben we nu wel bereikt?}

De modernisering van de opleidingen brengt een zeer belangrijke discussie op tafel: wat willen we opleiden en hoe willen we opleiden. De opleidingen staan overal flink op de agenda. Die discussie gaat gepaard met het genereren en het verspreiden van wetenschap over opleiden. Dat is een zeer belangrijk winstpunt en ik geloof dat de opleiding van artsen en specialisten mede daardoor in ons land relatief goed loopt.

In deze aflevering van TMO wordt wetenschap verspreid over het opleiden van huisartsen (Locher en Blankenstein), over e-learning (Mostaert et al.) en over ervaring met instroom van buitenlandse artsen in geneeskundeopleidingen (Herfs en Haalboom). Jan van Dalen verrast ons met rolmodellen uit onze jeugd (zo vernoemde ik mijn zoon naar Jim Morrisson). In de visie van de commissie Dijsselbloem is het genereren en verspreiden van wetenschap en ervaring essentieel voor een goed onderwijsproces. TMO zit dus op het goede spoor. Ik verwacht voor de toekomst in TMO nog heel wat leerzame lessen uit de modernisering van de medische vervolgopleidingen. Hopelijk zal er niet te veel herhaling in zitten wanneer we die lessen vergelijken met die van de commissie Dijsselbloem.

\section{Fedde Scheele}

\section{Literatuur}

1. Parlementair onderzoek onderwijsvernieuwingen. Commissie Dijsselbloem. http://www.tweedekamer.nl/images/kst113842.8s_tcm118-149847.PDF [bezocht 3-3-08] [Parliamentary Inquiry into introduction in education of Dijsselbloem Committee]. 


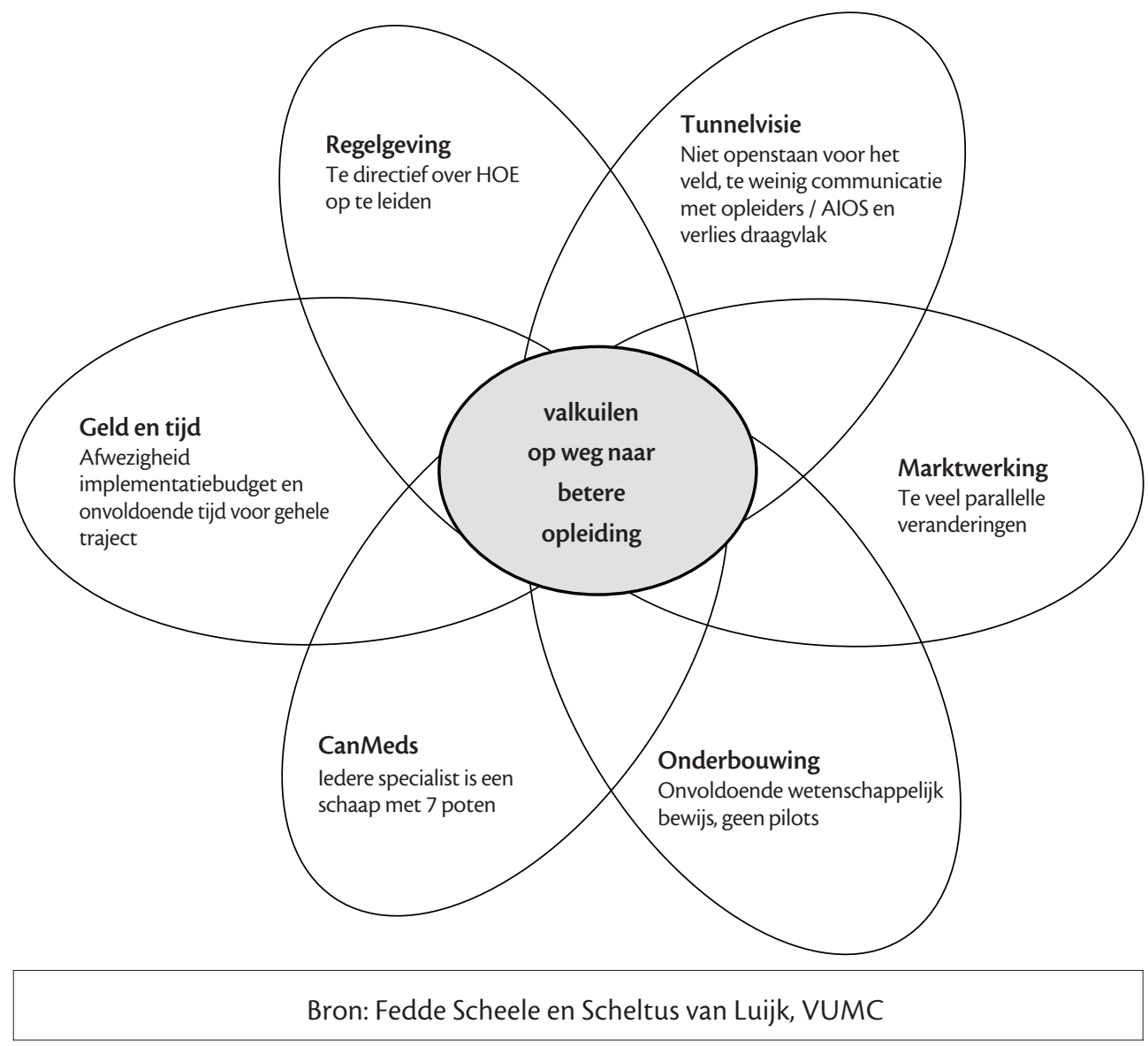

Figuur 1. De 'Dijssel-bloem'. Spiegeling van het rapport van de commissie Dijsselbloem aan de modernisering van de specialistenopleiding. 